\title{
Characterisation of the Wear of the Roller Cone Drill Bit Caused by Improperly Chosen Drilling Regime
}

\author{
Karakterizacija obrabe kotalnega dleta povzročene $\mathrm{z}$ nepravilno \\ izbiro režima vrtanja
}

\author{
Jurij Šporin* \\ Faculty of Natural Sciences and Engineering, Department of Geotechnology, Mining and Environment, University of Ljubljana, \\ Aškerčeva 12, Ljubljana, Slovenia \\ * jurij.sporin@ogr.ntf.uni-lj.si
}

\begin{abstract}
The rapid drop in the penetration rate or failure of the drill bit during the drilling process delays the drilling process. In our investigation, the 'in situ' drilling parameters were monitored during the drilling process along with the roller cone drill bit, which is suitable for drilling in soft rock formations (IADC 136). The drill bit was thoroughly examined to determine its damage and wear occurred during drilling along with decreasing penetration rate. The modern and standardised investigation methods were used to analyse the rock materials and the micro- and macro-structure of the materials of the roller cone bit. The analyses were performed by means of optical and electron microscopes, simultaneous thermal analysis of the steel materials, analysis of the chemical composition of the materials of the drill bit and determination of the geomechanical parameters of the drilled rock. The resulting wear, localised fractures and cracks were quantitatively and qualitatively defined and the parameters were correlated to the drilling regime and the rock material. The results of our investigation of the material of the roller cone bit can serve as a good basis for the development of new steel alloys that can withstand higher temperatures and allow effective drilling without structural changes of the steel material.
\end{abstract}

Keywords: drilling regime, roller cone bit, wear, reduced penetration rate, change of the material properties.

\section{Izvleček}

Upad napredka vrtanja ali odpoved dleta med vrtanjem imata za posledico daljši čas izvajanja vrtalnih del. V toku raziskave obrabe kotalnega dleta IADC 136, ki je namenjen uporabi pri vrtanju skozi mehkejše kamnine, so se izvajale opazovanja in meritve vrtalnih parametrov. Po končanem odseku vrtanja, ko je hitrost napredovanja drastično padla, se je kotalno dleto natančno pregledalo za ugotovitev nastalih poškodb med vrtanjem. Za ugotavljanje in določanje načina obrabe so se uporabile moderne in standardne metode. Izvedla se je analiza hribinskega materiala skozi katerega se je vrtalo, ter analiza mikro in makro strukture materialov kotalnega dleta. Analiza materialov se je izvedla z uporabo optičnega in elektronskega mikroskopa, simultane termalne analize jekla kotalnega dleta, določila se je kemijska sestava jekla kotalnega dleta in geomehanske karakteristike hribinskega materiala skozi katerega se je vrtalo. Izražena obraba kotalnega dleta se je kvantitativno in kvalitativno ovrednotila v povezavi z režimom vrtanja in karakteristikami hribine skozi katere se je vrtalo. Rezultati naše raziskave materialov kotalnega dleta lahko služijo kot dobra osnova za razvoj novih jeklenih zlitin, ki bodo prenašale visoke temperature, ki nastajajo med vrtanjem, brez strukturnih sprememb jeklenih materialov.

Ključne besede: režim vrtanja, kotalno dleto, obraba, zmanjšani napredek vrtanja, sprememba lastnosti materiala. 


\section{Introduction}

The time of effective drilling operations depends on the properties of the materials from which the roller cone bit components are manufactured. The roller bit will wear out due to the consequences of effects of the rock material it is drilling through and the drilling regime. The penetration rate decreases due to the wear of the bit.

The following factors among all have a significant influence on the effective operation of the roller cone bit are the steel material from which the rollers and teeth of the bit are made, the drilling regime (load on the bit during drilling, torque, number of bit revolutions and the quantity and properties of the drilling fluid) and the properties of rock drilled.

We analysed the mechanical properties of the steel material of the roller cone bit IADC 136, $155.57 \mathrm{~mm}$ (6 1/8"), which was drilling through carbonatic siltstone where sandstone plates and rare thin layers of clay and limestone exist in a total length of $87.89 \mathrm{~m}$.

Our research focused on the resistance of the steel material of the roller cone bit to the rock material using a selected drilling regime.

To accomplish this, it was necessary to use scientific approaches to determine the causes that lead to wear of the bit and identify the weak points on the bit that need to be technologically modified in order to enhance the effective drilling time.

\section{Drilling Principle of the Roller Cone Drill Bit}

The roller cone bit contains cutting elements, i.e. teeth or inserts, which are mounted on the rollers. The rollers, which are inserted into the bearings of the bit, rotate around their axis. They are driven by rotating drilling rods that drives the body of the drill bit on which the roller is mounted. Nozzles (outlet) for the drilling fluid are attached to the bit body to effectively remove the rock particles from the borehole bottom of the borehole and to cool the rollers and teeth of the bit. The drilling fluid flows through the nozzles from the inside of the drill pipes into the area of the bit. When the orifice is reduced, which is the ratio of the cross-section of the drill bit to the cross-section of the nozzles, the velocity of the drilling fluid flow is increased significantly. The increasing velocity of the drilling fluid has a positive effect on the flow of the drilling fluid around the rollers, which effectively removes the drilled rock particles from the bottom of the borehole and contributes to the fracture of the borehole, especially in the softer, poorly bonded rocks [1-20].

The roller cone bit with steel teeth, which is investigated here, is used in softer, poorly bonded rock formations. The teeth of the rollers are large and sharp so that they can penetrate deep into the soft rock structures where the rock is crushed and removed from the crushed area. The teeth are protected with a carbide coating to improve durability, which increases the effective operating time. The axes of the rollers do not intersect at the point of the vertical axis of the bit, but do have an offset corresponding to the point of the vertical axis of the bit. The offset of the roller axis is normally in the range of $2^{\circ}-5^{\circ}$.

The load on tooth $F$, which causes the tooth to penetrate the rock $(h)$, is a linear combination of the force acting against the surface at the tip of the tooth and the force acting against the surface formed by the inclined surfaces of the tooth.

When rollers and bits with teeth on rollers are made of the same material, we could state the following [21]:

$F=\left(C_{1} \cdot w+C_{2} \cdot h\right) \cdot l \cdot \sigma_{p^{\prime}}$

where $F$ is the load on a single tooth of the bit; $C_{1}$ is the coefficient of friction on the surface at the tooth tip (-); $w$ is the tooth width (m); $C_{2}$ is the coefficient of friction on the tooth surface in contact with the rock $(-) ; h$ is the penetration depth of the tooth $(\mathrm{m}) ; l$ is the tooth length $(\mathrm{m})$ and $\sigma_{p}$ is the compressive strength of the rock $(\mathrm{Pa})$.

The result of the reaction force $F$ on the tooth of the bit in contact with the rock is equal to the load generated on the bit [22] and is given by:

$\mathrm{WOB}=n_{t} \cdot F$, 
where WOB is the weight on the bit $(\mathrm{N})$ and $n_{t}$ is the number of teeth in contact with the rock. The volume of the crater of the crushed rock $V_{\text {crat }}\left(\mathrm{m}^{3}\right)$ created by one tooth, assuming that the crater has a conical shape, is stated by the following equation [22]:

$V_{\text {crat }}=\frac{1}{3} \cdot \pi \cdot r_{\text {crat }}^{2} \cdot h$,

where $r_{\text {crat }}$ is the crater radius (m) and $h$ is the crater depth (m).

By determining the volume of a single crater formed by a single tooth, the penetration rate can be evaluated, which is defined by the volume of the rock craters on the entire cutting surface of the roller cone bit in number of revolutions [22] and can be stated as follows.

$\mathrm{ROP}=\frac{V_{c r a t} \cdot n_{t} \cdot \mathrm{RPM}}{A_{b i t}}$,

where ROP is the rate of penetration $(\mathrm{m} / \mathrm{s})$; $V_{\text {crat }}$ is the volume of the crater of the removed rock $\left(\mathrm{m}^{3}\right)$; RPM is the number of rotations of the bit $\left(\mathrm{s}^{-1}\right)$ and $A_{b i t}$ is the cutting area of the bit $\left(\mathrm{m}^{2}\right)$. As the bit advances through the rock, the teeth of the roller cone bit wear out. Further, the parameters that influence the penetration rate (ROP) of the roller cone bit are focused here to determine the wear of the bit. Bourgoyne and Young $[23,24]$ defined these as influential parameters as stated in Eq. (5).

$\mathrm{ROP}=f_{1} \cdot f_{2} \cdot f_{3} \cdot f_{4} \cdot f_{5} \cdot f_{6} \cdot f_{7} \cdot f_{8^{\prime}}$

where $f_{1}$ is the effect of formation strength or rock durability; $f_{2}$ is the effect of formation depth; $f_{3}$ is the effect of formation compaction or pore pressure; $f_{4}$ is the effect of differential pressure; $f_{5}$ is the effect of bit diameter and bit weight; $f_{6}$ is the effect of rotary speed; $f_{7}$ is the effect of tooth wear and $\mathrm{f}_{8}$ is the effect of bit hydraulics.

We investigated the wear of the roller cone bit, the occurrence of damage and the change in the properties of the bit materials under the conditions of the properties of the material drilled through, the drilling regime (weight on the bit, speed, etc.) and the hydraulics of the drilling fluid in the area of the bit.

\section{Materials and Methods}

When determining the characterisation of the wear of the roller cone bit at the time of the investigations, detailed analyses were made against the drilling regime, the materials from which the bit was made and the rock through which the bit was drilled. To achieve this purpose, in the first phase, we carried out a survey of the bit, which included an overview of the condition of the bit after drilling according to the IADC bit dull standard. In this part, we investigated the condition of the teeth and rollers of the bit after drilling through known rock.

While drilling through the known rock, the following drilling parameters of drilling regime were monitored:

- The penetration rate;

- The length of the drilled interval;

- The load on the bit;

- The bit RPM; and

- The amount, pressure and properties of the drilling fluid.

We carried out a complete analysis of the steel materials of the roller cone bit, which included the following investigations:

- Analysing the micro- and macrostructure of roll cone bit materials with an reflected light microscope (Olympus BX61 and Olympus SZ61 stereo microscope using the Analysis 6.0 image analysis system);

- The composition of the carbide coating of bit teeth using the XRF (X-ray fluorescence) method (Thermo NITON XL3t XRF analyser);

- A cross-sectional view of bit teeth using a scanning electron microscope (SEM) and EDS analysis (energy dispersive X-ray spectroscopy) (Jeol JSM 5610);

- A dilatometric analysis of tooth steel and tooth carbide coating with the low temperature dilatometer (Baehr-Thermoanalyse GmbH DIL 801);

- Chemical analysis of the components of the teeth and rollers with an ICP (inductively coupled plasma) analyser (ICP-OES Agillent 720); 
- DSC (Differential Scanning Calorimetry) of tooth carbide coating and tooth steel with a thermal analyser (NETZSCH STA 449 C Jupiter) and

- Vickers hardness tests of the tooth steel with a $100 \mathrm{~g}$ load using microhardness tester (Shimadzu type M).

The properties of the rock obtained by sampling were estimated based on the analysis of Rock Lab 1.0.

\section{Results}

The results of our analysis show the way and the mechanisms that cause wear of the bit material at fixed or established rock properties in connection with the operating parameters of the drilling.

\section{Drilling work}

Drilling was carried out with a 1992 N-1000 drill rig. The interval in which we observed the performance of the IADC 136 roller cone drill bit included a length of drilling interval from $1535.15 \mathrm{~m}$ to $1623.04 \mathrm{~m}$ depth, corresponding to a length of $87.89 \mathrm{~m}$. The penetration rate during the observed interval ranged from $0.2 \mathrm{~m} / \mathrm{h}$ to $0.4 \mathrm{~m} / \mathrm{h}$. The remaining drilling regime parameters are shown in Table 1.

The 40 mass. $\%$ bentonite drilling fluid was used during drilling. The properties of the drilling fluid are shown in Table 2.

Table 1. Drilling regime parameters

\begin{tabular}{llll} 
Parameters & Units & Value & Value \\
\hline Depth & $\mathrm{m}$ & $1535.15-1600.00$ & $1600.00-1623.04$ \\
\hline Rotary speed & $\mathrm{rpm}$ & 35 & 45 \\
\hline Load on drill bit & $\mathrm{kN}$ & 30 & 40 \\
\hline Pump pressure & $\mathrm{MPa}$ & 5.5 & 5.5 \\
\hline Pump capacity & $\mathrm{m}^{3} / \mathrm{min}$ & 0.845 & 0.845 \\
\hline
\end{tabular}

Table 2. The properties of drilling fluid

\begin{tabular}{lll} 
Parameters & Units & Value \\
\hline Density & $\mathrm{kg} / \mathrm{m}^{3}$ & $1150-1170$ \\
\hline Viscosity (Fann Funnel) & $\mathrm{s}$ & $45-48$ \\
\hline Plastic viscosity (Fann Viscosimeter) & $\mathrm{mPas}$ & $16-18$ \\
\hline $\mathrm{pH}$ & - & 9.5 \\
\hline Filtration & $\mathrm{mL} / 30 \mathrm{~min}$ & $9.8-10$
\end{tabular}

\section{Rock Material Properties}

The rock material we drilled through was regularly sampled from drilling fluid. Each rock sample was examined and compared to a predetermined lithological column based on the results of geophysical and laboratory measurements in the surrounding boreholes.

As far as the lithology of the material of the drilled interval concerned, silty claystone is dominant and layers of carbonatic siltstone with sandstone plates and thin layers of clay and limestone occur in the lower and upper parts of the sequence.

The geomechanical properties of the drilled borehole section were evaluated based on experience. The strength properties were evaluated using the Hoek-Brown's criterion using RockScience software, Rock Lab 1.0.

The estimated rock properties values for the carbonate silt are shown in Table 3.

The estimated rock properties values for limestone are shown in Table 4. 
Table 3. Results of the rock properties - carbonatic siltstone

\begin{tabular}{lll} 
Parameters & Units & Value \\
\hline Cohesion & $\mathrm{MPa}$ & 0.722 \\
\hline Elastic module & $\mathrm{MPa}$ & 9375 \\
\hline Angle of internal friction & $\circ$ & 20.94 \\
\hline Compressive strength & $\mathrm{MPa}$ & 25
\end{tabular}

Table 4. Results of the rock properties - limestone

\begin{tabular}{lll} 
Parameters & Units & Value \\
\hline Cohesion & $\mathrm{MPa}$ & 5.50 \\
\hline Elastic module & $\mathrm{MPa}$ & 28125 \\
\hline Angle of internal friction & $\circ$ & 38.42 \\
\hline Compressive strength & $\mathrm{MPa}$ & 75 \\
\hline
\end{tabular}

\section{Roller Cone Bit Investigation}

After drilling and cleaning, the drill bit was examined using the IADC dull grading system. We found that the teeth of the drill bit were evenly worn out and several individual teeth were broken. There are no obvious erosion effects due to the rock particles in the drilling fluid that would result in erosion of the steel material of the bit. The condition of roller cone bit after the length of drilled interval of $87.89 \mathrm{~m}$ is shown by Figure 1.

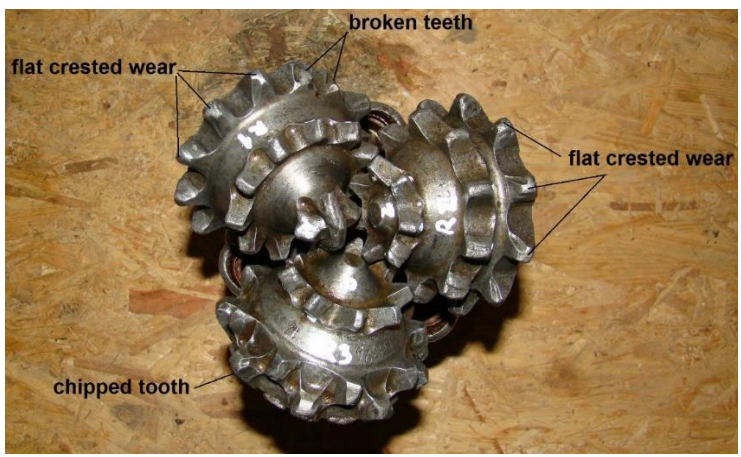

Figure 1. Characteristic dull of the roller cone bit after drilled interval.

\section{Investigations of Tooth Steel Material}

We examined the steel material and the carbide coating of the teeth.

The investigation of the chemical composition of the teeth material was carried out with an optical emission spectrometer (ICP). The results of the chemical composition of the examined steel (body) are shown in Table 5.
Table 5. Chemical analysis of the tooth material - body

\begin{tabular}{ll} 
Elements & Mas. \% \\
\hline $\mathrm{Mn}$ & 0.79 \\
\hline $\mathrm{Ni}$ & 0.74 \\
\hline $\mathrm{Cr}$ & 0.60 \\
\hline $\mathrm{Mo}$ & 0.50 \\
\hline $\mathrm{Cu}$ & 0.27 \\
\hline $\mathrm{Si}$ & 0.26 \\
\hline $\mathrm{C}$ & 0.17 \\
\hline $\mathrm{S}$ & 0.016 \\
\hline $\mathrm{P}$ & 0.011 \\
\hline
\end{tabular}

The results of the chemical analysis (Table 5) show that the steel material of the tooth body in this case is chromium, molybdenum, nickel low alloy steel, which is often used for case-hardened parts.

At SEM, we analysed metallographically the steel base of the tooth (chromium, molybdenum, nickel low alloy steel), the contact area between the tooth body and the carbide coating and the carbide coating itself. We have determined the chemical composition of the steel of each component of the tooth through the analysis of EDS. Figure 2 (SEM) shows the areas where metallographic tests are performed on the teeth. Tables 6-9 show the results of the EDS analyses for each component analysed.

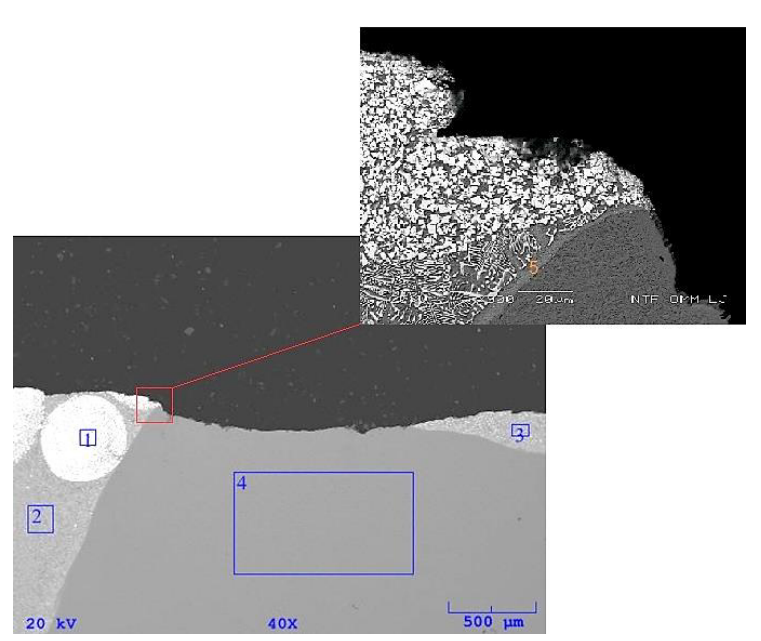

Figure 2. Scanning electron microscope (SEM) image of tip of the bit tooth. Position 1 - carbide material; Positions 2 and 3 - carbide coating matrix; Position 4 - tooth body and Position 5-mixed zone. 
Table 6. The elemental composition of carbide coating material (Figure 2 - Position 1)

\begin{tabular}{lll}
\multirow{2}{*}{ Elements } & \multicolumn{2}{l}{ Concentration } \\
\cline { 2 - 3 } & at.\% & wt.\% \\
\hline $\mathrm{W}$ & 55.415 & 79.539 \\
\hline $\mathrm{Co}$ & 42.380 & 19.500 \\
\hline $\mathrm{Fe}$ & 0.807 & 0.962 \\
\hline
\end{tabular}

Table 7. The elemental composition of the carbide coating matrix (Figure 2 - Position 2)

\begin{tabular}{lll}
\multirow{2}{*}{ Elements } & \multicolumn{2}{l}{ Concentration } \\
\cline { 2 - 3 } & at.\% & wt.\% \\
\hline $\mathrm{Fe}$ & 86.096 & 68.599 \\
\hline $\mathrm{W}$ & 1.709 & 29.094 \\
\hline $\mathrm{Ni}$ & 1.921 & 1.608 \\
\hline $\mathrm{Mn}$ & 0.892 & 0.699 \\
\hline
\end{tabular}

Table 8. The elemental composition of the carbide coating matrix (Figure 2-Position 3)

\begin{tabular}{lll}
\multirow{2}{*}{ Elements } & \multicolumn{2}{l}{ Concentration } \\
\cline { 2 - 3 } & at.\% & wt.\% \\
\hline $\mathrm{Fe}$ & 86.117 & 68.616 \\
\hline $\mathrm{W}$ & 11.103 & 29.124 \\
\hline $\mathrm{Ni}$ & 1.511 & 1.265 \\
\hline $\mathrm{Mn}$ & 1.269 & 0.995 \\
\hline
\end{tabular}

Table 9. The elemental composition of the tooth body (Figure 2 - Position 4)

\begin{tabular}{lll}
\multirow{2}{*}{ Elements } & \multicolumn{2}{l}{ Concentration } \\
\cline { 2 - 3 } & at.\% & wt.\% \\
\hline $\mathrm{Fe}$ & 95.427 & 95.385 \\
\hline $\mathrm{Ni}$ & 3.164 & 3.323 \\
\hline $\mathrm{Mn}$ & 0.660 & 0.649 \\
\hline $\mathrm{Mo}$ & 0.218 & 0.375 \\
\hline $\mathrm{Si}$ & 0.531 & 0.267
\end{tabular}

The elemental composition of the carbide coating material (Figure 2 - Position 1), which is determined by EDS, is shown in Table 6 .

The elemental composition of the carbide coating matrix (Figure 2 - Position 2), which is determined by EDS, is shown in Table 7 .

The elemental composition of the carbide coating matrix (Figure 2 - Position 3), which is determined by EDS, is shown in Table 8.

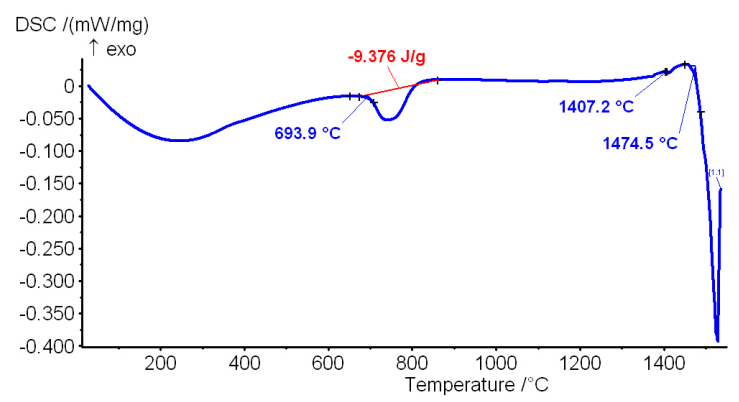

Figure 3. DSC heating curve of the steel of the tooth body.

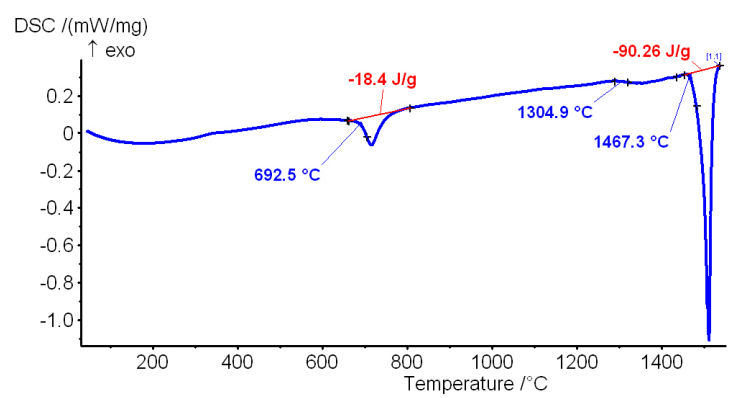

Figure 4. DSC heating curve of carbide coating.

The elemental composition of the tooth body (Figure 2 - Position 4), which is determined by EDS, is shown in Table 9.

We carried out a simultaneous thermal analysis (STA) (Figure 3) of the steel sample of the tooth body. The curve shows that eutectoid transformation in the solid state starts at a temperature of $693.9^{\circ} \mathrm{C}$ and also there is an endothermic peak. The process ends at $800^{\circ} \mathrm{C}$ when the metal matrix (iron) is transformed into a gamma-phase iron structure - austenite ( $\mathrm{g}$-Fe). The temperature $1407.2^{\circ} \mathrm{C}$ is the low temperature at which the eutectic structure or alloy begins to melt. The remaining material of the metal matrix (austenite) begins to melt at $1474.5^{\circ} \mathrm{C}$. The temperature of $1474.5^{\circ} \mathrm{C}$ is also the solidus temperature of the steel from which the tooth body is made.

The DSC (Differential scanning calorimetry) heating curve of the carbide coating of the teeth in the roller cone bit is shown in Figure 4. The carbide coating contains a thin layer of the mixing zone. The mixing zone is the area formed during the welding of the carbide coating to the tooth. It contains the properties of the steel of the tooth body and the carbide coating. At the 


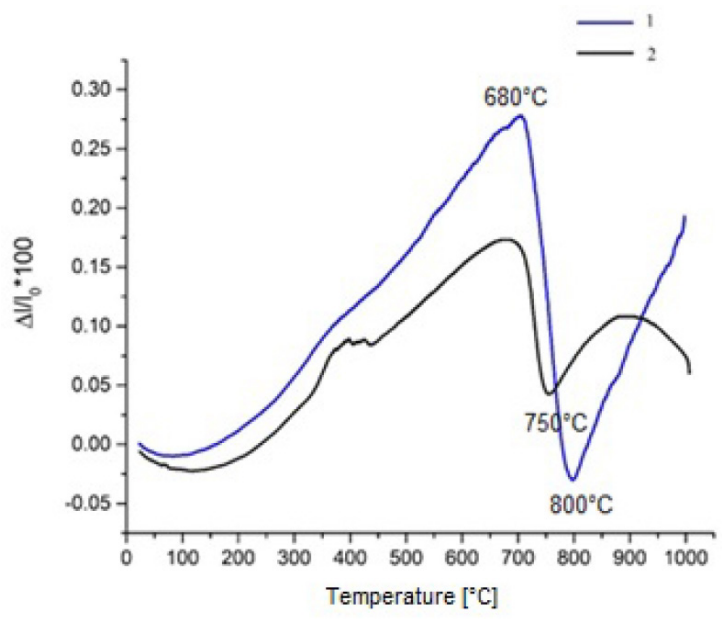

Figure 5. Dilatometric heating curve of the steel of the carbide coating and the steel of the tooth: 1 - tooth steel material (blue), 2 - carbide coating (black).

temperature $692.5^{\circ} \mathrm{C}$, the starting of the eutectoid transformation was detected. This transformation is related to the layer of the mixed zone. Therefore, this curve is not typical for carbide alloys. At the temperature of $1467.3^{\circ} \mathrm{C}$, the starting of melting process was detected.

Figure 5 shows the dilatometric curve of the steel of the carbide coating and the steel of the tooth body. It can be seen from the heating curve of the steel of the tooth body that the temperature of the eutectoid transformation increases linearly. The slope of the curve corresponds to the linear expansion coefficient for chromium, molybdenum and nickel low alloy steel, while the slope of the heating curve of the sample of the carbide coating containing a thin layer of the mixing zone is small. A lower curve angle of the carbide coating sample containing a thin layer of the mixing zone is the result of a lower coefficient of thermal expansion.

In view of the fact that the temperatures can locally reach up to $500^{\circ} \mathrm{C}$ during drilling despite intensive cooling, the curves show that the difference between the expansion properties is $0.05 \%$. Because of this difference, the mixing zone is the preferred area for the formation of internal stresses and hence suitable for the formation and propagation of micro-fractures. The diagram shows the beginning of the eutectoid transformation of the tooth body steel sample, which starts at $680^{\circ} \mathrm{C}\left(A_{\mathrm{c} 1}\right)$ and ends at a temperature of $800^{\circ} \mathrm{C}\left(A_{\mathrm{c} 3}\right)$. For the carbide coat-
Table 10. Results of the Vickers hardness test

\begin{tabular}{|c|c|c|c|c|}
\hline \multicolumn{2}{|c|}{$\begin{array}{l}\text { Diagonals } \\
\text { (mm) }\end{array}$} & \multirow{2}{*}{$\begin{array}{l}\text { Hardness } \\
\text { (HV0.5) }\end{array}$} & \multirow[t]{2}{*}{ Average } & \multirow[t]{2}{*}{ Note } \\
\hline d1 & d2 & & & \\
\hline 37.23 & 46.24 & 532.3198 & \multirow{11}{*}{594.5670} & \multirow{11}{*}{$\begin{array}{l}\text { Tip of } \\
\text { the tooth }\end{array}$} \\
\hline 36.22 & 37.55 & 681.5125 & & \\
\hline 36.4 & 40.81 & 622.1374 & & \\
\hline 37.99 & 41.33 & 589.4786 & & \\
\hline 37.54 & 41.66 & 591.2662 & & \\
\hline 37.43 & 39.54 & 626.0232 & & \\
\hline 37.57 & 39.86 & 618.6071 & & \\
\hline 36.33 & 42.41 & 598.1947 & & \\
\hline 38.87 & 42.45 & 560.8396 & & \\
\hline 38.48 & 42.45 & 566.2580 & & \\
\hline 39.01 & 42.84 & 553.6000 & & \\
\hline 44.99 & 47.95 & 429.3664 & \multirow{5}{*}{433.5184} & \multirow{5}{*}{$\begin{array}{l}\text { Tooth } \\
\text { body }\end{array}$} \\
\hline 44.44 & 48.37 & 430.5701 & & \\
\hline 44.61 & 47.78 & 434.4937 & & \\
\hline 44.09 & 47.10 & 446.0042 & & \\
\hline 45.14 & 48.04 & 427.1575 & & \\
\hline 33.28 & 37.13 & 748.1087 & \multirow{5}{*}{784.1543} & \multirow{5}{*}{$\begin{array}{l}\text { Carbide } \\
\text { coating- } \\
\text { matrix }\end{array}$} \\
\hline 31.73 & 34.04 & 857.3887 & & \\
\hline 33.64 & 36.53 & 753.2349 & & \\
\hline 34.58 & 36.51 & 733.8654 & & \\
\hline 30.41 & 36.51 & 828.1739 & & \\
\hline 24.67 & 25.96 & 1446.830 & \multirow{2}{*}{1458.984} & \multirow{2}{*}{$\begin{array}{l}\text { Carbide } \\
\text { coating- } \\
\text { base }\end{array}$} \\
\hline 24.43 & 25.78 & 1471.137 & & \\
\hline
\end{tabular}

ing sample containing a thin layer of the mixed zone, eutectoid transformation starts at $750^{\circ} \mathrm{C}$. On the curve of the carbide coating sample containing a thin layer of the mixing zone, a deviation is observed which can be associated with the eutectoid transformation of the thin layer of the mixing zone, but the temperature is slightly higher. The reason for this higher temperature is due to the chemical composition of the mixing zone.

A Vickers hardness test was performed to determine the changes in the hardness properties of the tooth due to the effects of drilling. The measurement points are shown in Figure 6 and the results of the tests are shown in Table 10. The average hardness of the steel of the tooth body is $433.5184 \mathrm{HV}$. The average hardness of 


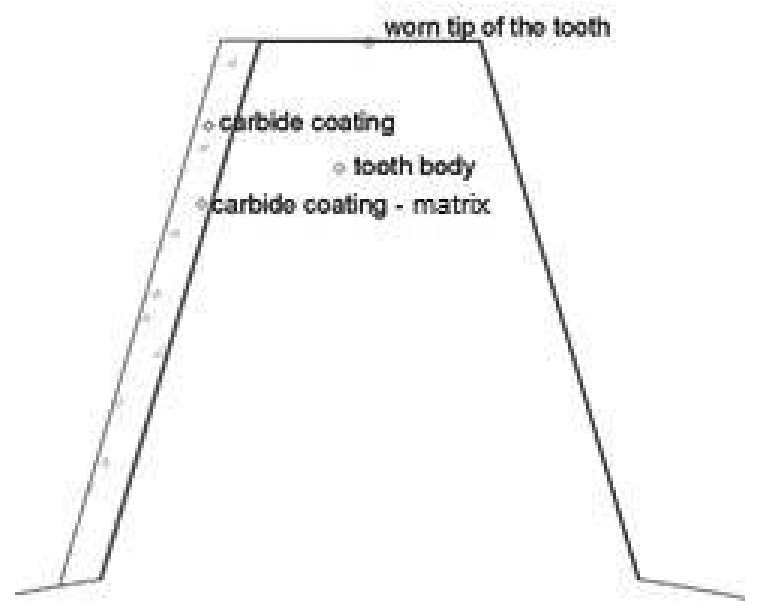

Figure 6. Display of measurement positions of Vickers hardness tests.

the steel at the tip of the teeth is much higher and is $594.5670 \mathrm{HV}$. The hardness of the carbide coating is, as expected, much higher and reaches up to $1471,137 \mathrm{HV}$.

\section{Discussion}

Monitoring of the operating parameters during drilling revealed that the roller cone bit was not loaded in accordance with the manufacturer's recommendations, which recommends that the bit load should be in the range of 15-27 kN. The load on the bit during drilling was between $30 \mathrm{kN}$ and $40 \mathrm{kN}$. In addition, the number of bit rotations was too low and they were between $35 \mathrm{rpm}$ and $45 \mathrm{rpm}$. The recommended number of bit rotations for this type of tool is between $60 \mathrm{rpm}$ and $100 \mathrm{rpm}$.

It can be noted that the bit was overloaded with weight and the number of bit rotations was too low.

Examination of the microscopic image showed that the tips of the teeth were exposed to high temperatures and stresses. The influence of high temperatures and loads is shown in Figure 7.

Figure 7 shows the tip of the tooth that was in contact with the rock. We can see changes in the colour of the steel, which changes from blue tones (at the point of contact between the rock and the steel) to brown tones that change the light from top to bottom.

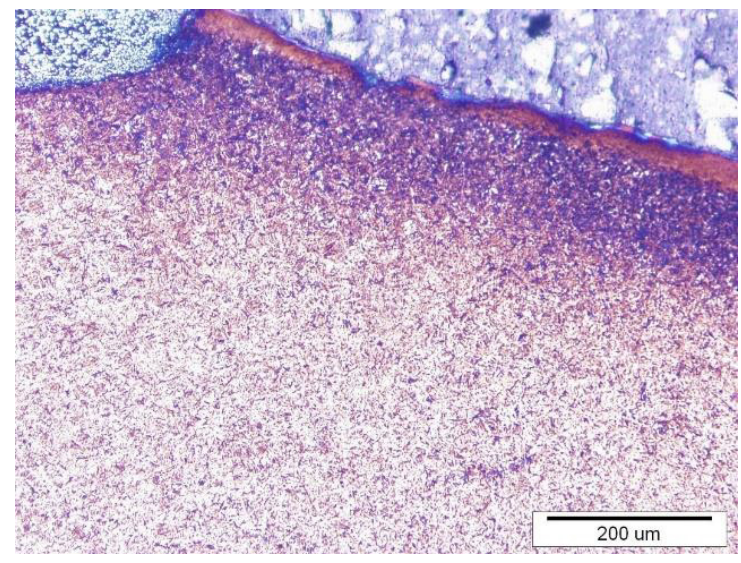

Figure 7. Microscopic photo of the tip of the tooth.

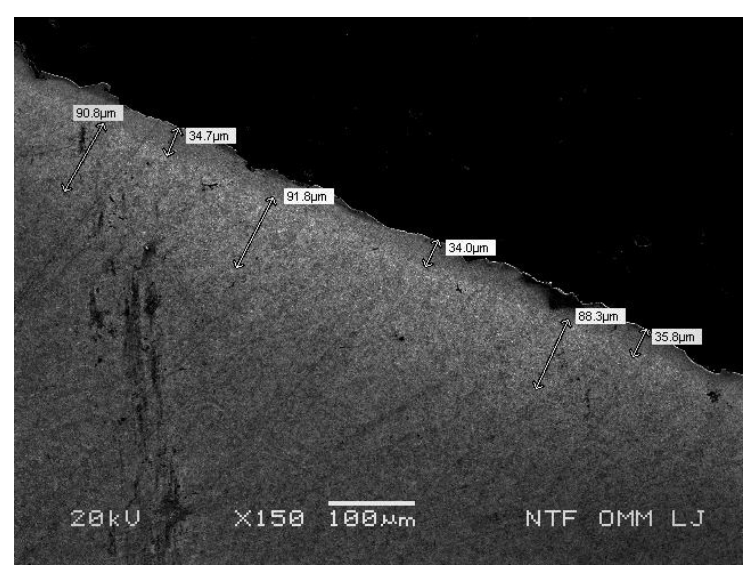

Figure 8. A view at the tip of tooth that was in contact with the rock.

Because of the apparent colour change previously observed under the optical microscope, the sample was examined with a scanning electron microscope (SEM). A characteristic view of the microstructure of the area with a SEM is shown in Figure 8.

Figure 8 shows the condition of the tooth tip that was in contact with the rock during drilling. A change in the microstructure of the steel on the surface was observed. The change in the steel structure can be observed in two layers. The first layer, where the change is noticeable, is up to a thickness of $36 \mu \mathrm{m}$. The second layer, in which the change in microstructure is less pronounced but still noticeable, moves to a depth of up to $92 \mu \mathrm{m}$.

The change in the steel microstructure of the tooth was due to the high temperatures and 
mechanical stresses that occurred during drilling when the tip of the tooth was in contact with the rock. When the roller cone bit is rotated around its axis, the teeth got cooled. The teeth that were not in contact with the rock were cooled by the drilling fluid flowing out from the nozzles of the bit. In this situation, a temperature change occurs on the surface of the teeth when their temperature is very high and they are washed with drilling fluid at a lower temperature. The other reason for microstructural changes in the steel is that the bit was overloaded during drilling and the number of revolutions was too low when compared to the load. The consequence of such a drilling regime is the increase in temperature of the material at the tooth tip, which in combination with the load results in the hardening of the material at the tooth tip. Because of this reason the hardness of the steel material increased. The measured hardness (Vickers hardness) at that time was on average about $160 \mathrm{HV}$ higher than the hardness of the steel material in the middle of the tooth.

Using differential scanning calorimetry (DSC), we found that the temperature of the eutectoid point is $699.2^{\circ} \mathrm{C}$ and its completion occurs at a temperature of $800^{\circ} \mathrm{C}$. Due to the intensive cooling of the teeth under the influence of the drilling fluid, the microstructural change process occurred only in the steel layer down to a depth of $92 \mu \mathrm{m}$. Microstructural changes are only noticeable on the upper side of the teeth, while no changes were observed on the sides. The changes in the steel structure occurred mainly due to excessive operating temperatures and loads on the selected steel. As demonstrated by DSC and dilatometric analysis, the temperature at the beginning of the transformation from ferrite to austenite is about $680^{\circ} \mathrm{C}$ for the selected steel. This means that the temperature of $680^{\circ} \mathrm{C}\left(A_{c 1}\right)$ is a point at which recrystallisation of the steel is rapidly accelerated. The recrystallisation temperature for steel, when calculated for theoretical information, is somewhere around $0.4 \times T_{L}\left(T_{L}\right.$ - liquidus temperature, ${ }^{\circ} \mathrm{C}$ ) [25]. Using the software Thermo-Calc for thermodynamic modelling of the equilibrium phase, we calculated the liquidus temperature, which was $1511^{\circ} \mathrm{C}$ for the selected steel. Therefore, the recrystallisation temperature

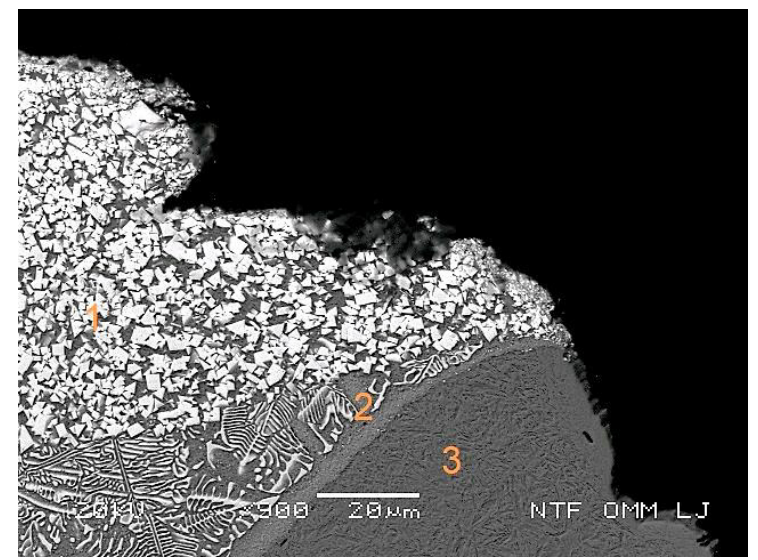

Figure 9. Photography of tooth steel material. Position 1 carbide coating; Position 2 - mixed zone and Position 3 tooth steel (body).

for the analysed steel is about $604^{\circ} \mathrm{C}$. We also calculated the equilibrium eutectoid temperature $\mathrm{A}_{e 1}$ and the transition temperature $\mathrm{A}_{e 3}$ with the same software. The temperature of t6he former was $685^{\circ} \mathrm{C}$ and the latter was $811^{\circ} \mathrm{C}$. The equilibrium eutectoid temperature $A_{e 1}$ and the transition temperature $\mathrm{A}_{e 3}$ were also calculated. The calculated values are similar to the values obtained from the dilatometric analysis of the steel $\left(680^{\circ} \mathrm{C}\right.$ and $\left.800^{\circ} \mathrm{C}\right)$, assuming that the temperatures obtained from the calculation are in equilibrium. This confirmed the results of the dilatometric analysis.

Due to the influence of high temperatures and rapid cooling, the carbide coating on the upper surface of the tooth gets decayed. The difference between the temperature-expansibility coefficients of the steel material and the carbide form was found by a dilatometric test at low temperature. This difference is significant as it causes increase in internal stress in the mixed zone. The mixed zone is formed by welding the carbide coating onto the tooth steel and represents a mixture of dissolved steel material of the tooth and the carbide coating (Figure 9). In the mixed zone, during the heating and cooling processes, internal stresses begin to increase due to the different temperature coefficients of the materials, which lead to initiation and propagation of cracks.

Cracks were observed on the edges of the teeth, which progressed through the carbide coating to the steel of the tooth (body) (Figure 10). The occurrence of such cracks can be attributed 


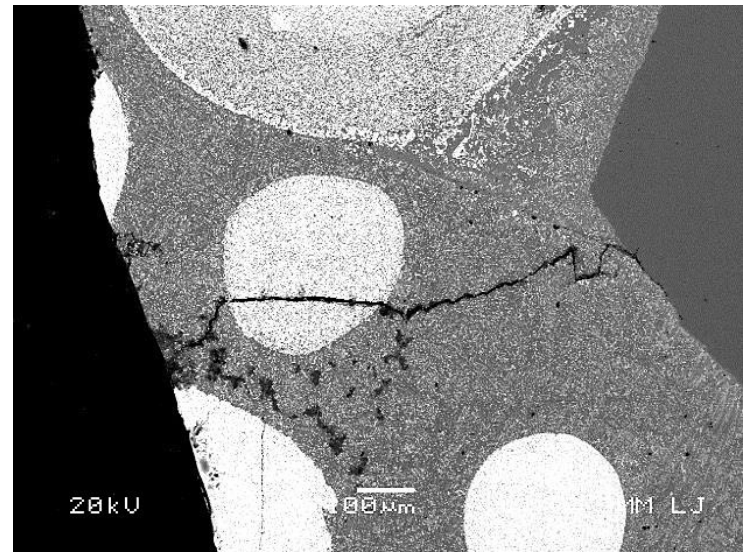

Figure 10. Photography of cracks through carbide coating.

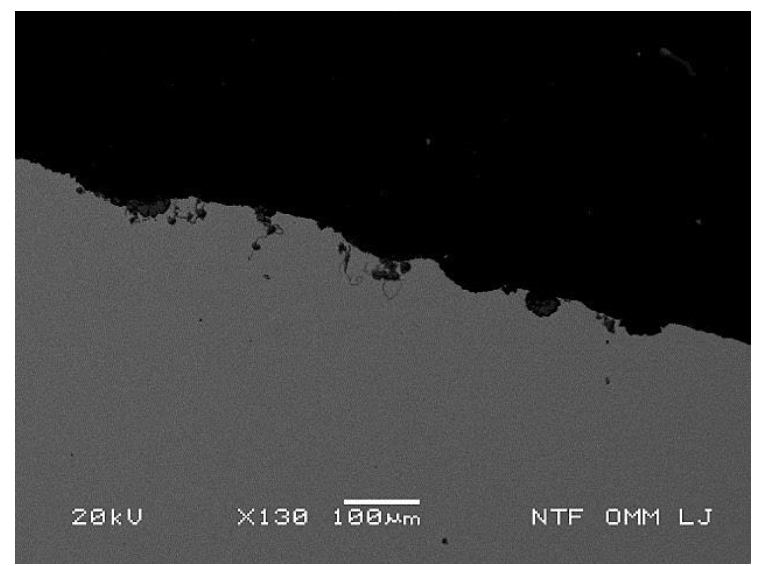

Figure 11. Erosion channels at the top of the tooth.

to the excessive load on the bit during drilling and the stress accumulation due to the weight load of the bit. The carbide coating is tough and erosion resistant, but brittle, which causes it to crack under excessive load and lateral forces. Due to the formation of such cracks at the tooth edges, the carbide coating is sheared or eroded, which resulted in a chipped tooth.

The erosion effect caused by aggressive particles in the drilling fluid could not be expressed comprehensively so far, as only a short length of $87.89 \mathrm{~m}$ was drilled with this drill bit. Microscopic images show smaller erosion microchannels, which are not largely pronounced (Figure 11). Erosion microchannels occur only in the area of the tooth tip. There are no erosion channels along the tooth edges that are not protected by carbide coatings, which is partly due to the geometry of the teeth. Here, the teeth sides are quite steep, which means that the drilling fluid with abrasive particles leaves the tooth area within a short time.

\section{Conclusions}

In this article, we have described the wear of the IADC 136 roller cone bit drilled into a known standard rock material. The bit wear was characterised by the analysis of the different metallurgical properties of the steel and the carbide coating of the teeth of the bit, which are related to the drilling regime and the properties of the rock material. During drilling, the teeth of the bit are heated when are in contact with the rock and then cooled by the influence of the drilling fluid. At this stage, there is a compressive load on both the steel of the tooth and its carbide coating. Internal stresses developed in the materials of the bit teeth due to the load on the bit can expand through the elastic zone and reach the plastic zone, which results in local dissolution of the carbide coating and a local increase in the hardness of the steel material.

Using an IADC 136 roller cone bit, the length of interval $87.89 \mathrm{~m}$ was drilled into a carbonatic siltstone with sandstone plates and thin layers of clay and limestone. The wear of the teeth of the roller cone bit was mainly observed at the tooth tip. During the systematic investigation of the steel structure of the teeth and the carbide coating, it was found that the structure of the steel material at the tip of the teeth was partially changed by the influence of high deformations. This change, which was reflected in the increase in the hardness of the steel material, was higher at the tip of the tooth which is in contact with the rock by $160 \mathrm{HV}$ than at the tooth body. The change in the hardness of the steel material, expressed as a layer parallel to the tooth tip, extends to a depth of about $36 \mathrm{~mm}$. The formation of this layer with a higher degree of hardness can be explained by the implementation of the weight on the drill bit (WOB), which was higher than the recommended and relatively low rotation (RPM), and it was lower than the recommended. The increase in the temperature of the tooth material during drilling was due to excessive loads and inefficient cooling, resulting in micro-fatigue reaching the 
plastic zone of the steel material at the tip of the tooth. The tip of the tooth was worn out by a modified microstructure due to friction along the rock, and underneath it, a new layer with a modified microstructure formed periodically. From this, it can be concluded that the correct choice of roller cone bit can be recommended for a specified type of rock and operating parameters (WOB, RPM, drilling fluid) since it has a significant influence on the wear of the roller cone bit and thus on the extension or reduction of the effective operating time of the roller cone bit.

The results of our investigation of the materials of the roller cone bits can provide a base and guidelines for the development of new steel alloys that can withstand higher temperatures and allow effective drilling without structural changes in the steel material.

\section{References}

[1] Al-Sudani, J.A. (2017): Real-time monitoring of mechanical specific energy and bit wear using control engineering systems. Journal of Petroleum Science and Engineering, 149, pp. 171-182, DOI: 10.1016/j. petrol.2016.10.038.

[2] Bingham, M.G. (1965): A New Approach to Interpreting Rock Drillability. Petroleum Publishing Co.: Tulsa, OK, USA, 93 p.

[3] Cheatham, J.B. (1958): An analytical study of rock penetration by a single bit tooth. In: Proceedings of the 8th Drilling and Blasting Symposium, Minnesota, MN, USA.

[4] Dagrain, F., Lamine, E., Delwiche, R., Golard, N. (2013): Characterization of the performances of small diameter drill bits for the optimization of the drilling parameters. In: Proceedings of the 2 nd International Conference on Stone and Concrete Machining (ICSCM), Dortmund, Germany.

[5] Dutta, P.K. (1972): A theory of percussive drill bit penetration. International Journal of Rock Mechanics and Mining Sciences \& Geomechanics Abstracts, 9, pp. 543-567, DOI: 10.1016/0148-9062(72)90044-7.

[6] Eremin, E.N., Yurov, V.M., Guchenko, S.A., Laurynas, V.C., Kasymov, S.S. (2016): Antifriction Superhard Coatings for Drill Bits and Boring Cutters. Procedia Engineering, 152, pp. 608-612, DOI: 10.1016/j.proeng.2016.07.663.
[7] Evans, I., Murrell, S. (1962): Wedge penetration into coal. Colliery Engineering, 39, 11.

[8] He, W., Chen, Y., He, J., Xiong, W., Tang, T., OuYang, H. (2016): Spherical contact mechanical analysis of roller cone drill bits journal bearing. Petroleum, 2, pp. 208-214, DOI: 10.1016/j.petlm.2016.03.002.

[9] Jones, H.G., Norgren, S.M., Kritikos, M., Mingard, K.P., Gee, M.G. (2017): Examination of wear damage to rock-mining hardmetal drill bits. International Journal of Refractory Metals and Hard Materials, 66, pp. 1-10, DOI: 10.1016/j.ijrmhm.2017.01.013.

[10] Karasawa, H., Ohno, T., Miyazaki, K., Eko, A. (2016): Experimental results on the effect of Bit wear on torque response. International Journal of Rock Mechanics and Mining Sciences, 84, pp. 1-9, DOI: 10.1016/j.ijrmms.2016.01.013.

[11] Ma, D.K., Yang, S.L. (1985): Kinematics of the Cone Bit. Society of Petroleum Engineers Journal, 25, pp. 321-329, DOI: 10.2118/10563-PA.

[12] Maurer, W.C. (1965): Bit-Tooth Penetration Under Simulated Borehole Conditions. Journal of Petroleum Technology, 17, pp. 1433-1442, DOI: 10.2118/1260-PA.

[13] Naganawa, S. (2005): Dynamics modeling of roller cone bit axial vibration. Journal of the Japanese Association for Petroleum Technology, 70, pp. 333-346, DOI: $10.3720 /$ japt.70.333.

[14] Naganawa, S. (2012): Feasibility study on rollercone bit wear detection from axial bit vibration. Journal of Petroleum Science and Engineering, 82-83, pp. 140-150, DOI: 10.1016/j.petrol.2012.01.014.

[15] Njobuenwu, D.O., Wobo, C.A. (2007): Effect of drilled solids on drilling rate and performance. Journal of Petroleum Science and Engineering, 55, pp. 271-276, DOI: 10.1016/j.petrol.2006.08.012.

[16] Olsson, M., Yvell, K., Heinrichs, J., Bengtsson, M., Jacobson, S. (2017): Surface degradation mechanisms of cemented carbide drill buttons in iron ore rock drilling. Wear, 388-389, pp. 81-92, DOI: 10.1016/j.wear.2017.03.004.

[17] Paul, B., Sikarskie, D.L. (1965): A preliminary model for wedge penetration in brittle materials. Transactions of the American Institute of Mining Engineers, 232, pp. 373-383.

[18] Warren, T.M. (1981): Drilling Model for Soft-Formation Bits. Journal of Petroleum Technology, 33, pp. 963-970, DOI: 10.2118/8438-PA.

[19] Warren, T.M. (1987): Penetration Rate Performance of Roller Cone Bits. Society of Petroleum Engineers, 2, pp. 9-18, DOI: 10.2118/13259-PA. 
[20] Zhao, J., Zhang, G., Xu, Y., Wang, R., Zhou, W., Yang, D. (2018): Experimental and theoretical evaluation of solid particle erosion in an internal flow passage within a drilling bit. Journal of Petroleum Science and Engineering, 160, pp. 582-596, DOI: 10.1016/j.petrol.2017.10.068.

[21] Hareland, G., Wu, A., Rashidi, B.A. (2010): New Drilling Rate Model for Tricone Bit and Its Application to Predict Rock Compressive Strength. In: 44th US Rock Mechanic Symposium and 5th U.S.-Canada Rock Mechanics Symposium, Salt Lake City, UT, USA.

[22] Rashidi, B., Hareland, G., Wu, Z. (2015): Performance, simulation and field application modeling of rollercone bits. Journal of Petroleum Science and Engineering, 133, pp. 507-517, DOI: 10.1016/j.petrol.2015.06.003.

[23] Bourgoyne, A.T., Young, F.S. (1974): A Multiple Regression Approach to Optimal Drilling and Abnormal Pressure Detection. Society of Petroleum Engineers Journal, 14, pp. 371-384, DOI: 10.2118/4238-PA.

[24] Bourgoyne, A.T., Millheim, K.K., Chenevert, M.E., Young, F.S. (1991): Rotary Drilling Bits. In: Applied Drilling Engineering. SPE: Richardson, TX, USA, pp. 190-245.

[25] Totten, G.E. (2006): Steel Heat Treatment: Metallurgy and Technologies, 2nd ed. CRC Press: Boca Raton, Florida, USA, $848 \mathrm{p}$. 